\title{
FRANCHISE AGREEMENT UNDER THE LAW OF THE RUSSIAN FEDERATION
}

\author{
Roza Iosifovna Sitdikova. ${ }^{1}$ \\ Dmitriy Anatolievich Petrov ${ }^{2}$
}

\begin{abstract}
The franchise agreement in the Russian Federation is the main agreement that formalizes the relationship for organizing a business in the form of franchising. Under a franchise agreement, one party (franchisor) undertakes to provide the other party (user), for a fee, for a period or without specifying a period, the right to use in the user's business a set of exclusive rights belonging to the franchisor, including the right to a trademark, service mark, as well as rights to other objects of exclusive rights provided for by the agreement, in particular to a commercial designation, a secret of production (know-how). The paper analyzes the content and features of this agreement.
\end{abstract}

Keywords: Franchise agreement, franchising, legislation of the Russian Federation, entrepreneurial activity, business reputation, commercial experience.

\section{INTRODUCTION}

The franchise agreement in the Russian Federation is the main agreement that formalizes the relationship for organizing a business in the form of franchising. Franchising is known as a business model and has long established itself as an effective way of doing business in many countries (Baghdasaryan, 2008).

Chapter 54 of the Civil Code of the Russian Federation is devoted to the

\footnotetext{
${ }^{1}$ Roza Iosifovna Sitdikova, Doctor of Juridical Sciences, Professor, Department of Business and Energy law, Law Faculty, Kazan Federal University, e-mail: ms.rs575@ gmail.com. 0000-0003-4096-8932 Doctor of Juridical Sciences, Professor, Department of Business and Energy law, Law Faculty, Kazan Federal University, e-mail: ms.rs575@gmail.com. 0000-0003-4096-8932

2 Dmitriy Anatolievich Petrov, Doctor of Juridical Sciences, Associate Professor, Department of commercial law, Saint Petersburg State University, e-mail: d.petrov@spbu.ru. 0000-0003-1715-2863 Doctor of Juridical Sciences, Associate Professor, Department of commercial law, Saint Petersburg State University, e-mail: d.petrov@spbu.ru. 0000-0003-1715-2863
} 
franchise agreement in the legislation of the Russian Federation. The essence of these relations is actually defined in paragraph 2 of Article 1027 of the Civil Code of the Russian Federation. It is determined there that the franchise agreement provides for the use of a complex of exclusive rights, business reputation and commercial experience of the franchisor in any area of entrepreneurial activity.

The first paragraph of the same article gives the definition of the franchise agreement as an agreement under which a franchisor undertakes to provide the other party, who is called the user, the right to use in its entrepreneurial activities a set of exclusive rights to various objects. Such objects can be, for example, trademarks, service marks, commercial designation, trade secret (know-how) and other objects, the protection of which is provided for by the norms of the Civil legislation of the Russian Federation.

Here we should pay attention that according to the first paragraph of Article 1027 of the Civil Code of the Russian Federation, the subject of a franchise agreement is a set of exclusive rights, while from the meaning of paragraph 2, Article 1027 of the Civil Code of the Russian Federation, it can be assumed that the rights to business reputation and commercial experience are transferred under a franchise agreement. However, according to the legislation of the Russian Federation, business reputation and commercial experience refer to intangible goods and cannot participate in civil circulation, that is, they cannot be transferred under any agreement. At the same time, it is the business reputation and commercial experience accumulated by any subject of entrepreneurial activity, which are an important element of relations arising on the basis of a franchise agreement. Although the law does not directly indicate this, it is assumed that in this case there is a business reputation of the owner of exclusive rights, as well as the experience gained by it as a result of using the corresponding object of exclusive rights. Long-term positive experience of using a trademark in any field of business activity makes it a recognizable brand for the relevant goods or services. A person starting to engage in entrepreneurial activity can take advantage of their reputation and start working under a franchise agreement using the well-known means of individualization and the commercial experience of organizing a business. One of the famous examples of such work, 
GÊNERO E

INTERDISCIPLINARIDADE

the so-called franchising, is the organization of the business of the McDonald's network.

\section{MATERIALS AND METHODS}

The work uses various general scientific techniques and methods of logical cognition: analysis and synthesis, systemic, and formal-logical methods. The disclosure of the topic was facilitated by the use of formal legal, and comparative legal methods.

\section{RESEARCH RESULTS}

The franchise agreement is onerous. A user must pay remuneration to the franchisor on the terms established by the franchise agreement. These can be payments in the form of deductions from proceeds, fixed periodic payments, or any other form. The legislator in this regard does not limit the parties; everything is regulated by the agreement. The agreement can be concluded for a specific period or without specifying the period.

In a franchise agreement, the law allows an indication of a certain territory in which the use of exclusive rights, business reputation, and commercial experience is granted, that is, in fact, this territory determines the territory of the user's entrepreneurial
Vol no 02 | nº 01 | ISSN: 2675-7451 https://www.periodicojs.com.br/index.php/gei/index

activity in the relevant area. At the same time, in other spheres of entrepreneurial activity not related to the subject of the franchise agreement, the business entity is not bound by such restrictions.

In accordance with paragraph 3 of Article 1071, parties to a franchise agreement can be any business entities: commercial organizations and citizens registered as individual entrepreneurs. Obviously, both foreign citizens and legal entities can be a party to a franchise agreement. At the same time, the question of the so-called self-employed citizens remains open. In the case when citizens carry out their activities without registration as an individual entrepreneur, but also use a special tax regime, they can enter into a franchise agreement.

A franchise agreement is an important tool for regulating entrepreneurial relations in the form of franchising; it is in the agreement where the actually important conditions governing the relationship between a franchisor and a user are determined (Yuritsin, 2018). Based on the analysis of the content from Articles 1031 and 1032 of the Civil Code of the Russian Federation, which stipulate the obligations of a franchisor and a user, a number of requirements also follow from 
the content of the franchise agreement. So, under a franchise agreement, the franchisor must also transfer technical and other commercial documentation, also provide information related to the exercise of rights and the organization of the relevant business, instruct and train the user and its employees. The user is obliged to carry out the same activities as the franchisor and use the means of individualization in the ways provided for by the franchise agreement, including for the internal and external design of premises.

An important duty of a franchisor is to ensure the quality of the goods or services provided by the user of the same level as that of the person who provided the franchise. The user has the same responsibility. It is obliged not only to comply with the business conditions defined by the franchisor, but also to ensure the appropriate quality of goods and services under the control of the franchisor.

At the same time, the franchisor bears subsidiary responsibility for claims of non-conformity concerning the quality of goods, works or services carried out by the user under a franchise agreement. The franchisor bears joint responsibility with regard to the requirements for the user as a manufacturer of products (Article 1034 of the Civil Code of the Russian Federation).

The user is also obliged, unless otherwise provided by the agreement, to register the granting of the exclusive rights in the manner prescribed by the current legislation.

The user must comply with the terms of confidentiality and not disclose the information transmitted to it about the activity carried out under the franchise agreement. Such information may include, for example, data about the organization of activities, the procedure for using means of individualization and features of interior decoration of premises, know-how (Sitdikov, 2017), and others. The nature of the information constituting commercial value and the conditions for their use must be especially detailed in the agreement, which can be presented in court in the event of a dispute.

Compliance with all these requirements is ensured as a result of the agreement on the terms of the franchise agreement, as well as the establishment of measures of liability of the parties in order to ensure compliance with the terms of the concluded agreement.

In accordance with Article 1028 of the Civil Code of the Russian 
Federation, a mandatory written form of a franchise agreement is provided for; failure to comply with this requirement entails the agreement is null and void. Granting exclusive rights must be registered with the federal executive body for intellectual property in accordance with the requirements for licensing agreements.

In accordance with Article 1033

of the Civil Code of the Russian Federation, a franchise agreement may provide for certain restrictions on the rights of a franchisor and a user associated with the production of goods or the provision of services under this agreement. However, these restrictions should not contradict the antimonopoly legislation of the Russian Federation; otherwise, they may be invalidated at the request of the antimonopoly body or other interested person in the manner prescribed by law.

For the agreement under consideration, a characteristic feature is its exclusivity expressed in the granting to a user of the right to use in its entrepreneurial activities of a complex of exclusive rights to the results of intellectual activity and means of individualization, business reputation, and commercial experience belonging to the franchisor, subject to the adoption of a number of restrictions that limit the user's ability to independent competitive actions.

Thus, an users undertakes to act within the framework of the competitive strategy of a franchisor, acting in fact "under the name" of the latter in the eyes of consumers in the process of introducing the relevant goods, works, services into civil circulation, which explains the necessity and permissibility of such restrictions, raising them to the level of the essence of the agreement.

Exclusivity can also be observed in other contractual structures that are actively used in the field of entrepreneurship expressed in the establishment of a ban on cooperation on similar conditions with competitors of the franchisor and independent implementation of similar activities; limiting the term of the agreement and the territory of entrepreneurial activity. Such restrictions can be observed in commission agreements (clause 2, Article 990 of the Civil Code of the Russian Federation), agency services (Article 100 of the Civil Code of the Russian Federation), and a license agreement (clause 2 of clause 1, clause 1.1 of Article 1236 of the Civil Code of the Russian Federation). 
A direct indication in the law on the admissibility of the restrictive measure application often allows us to speak of a legislative exclusion from the general regime (Suvorov, 2019), in the absence of which an agreement with the condition of exclusivity contradicts the Russian legal order, since it limits the legal capacity and contractual freedom of the parties (Dudin, 2014; Kulakovsky, 2017).

The conclusion of a franchise agreement on terms of exclusivity cannot be considered as a refusal of citizens and legal entities to exercise their rights (which, as a general rule, could lead to their restoration by virtue of paragraph 2 of Article 9, paragraph 3 of Article 22, and Article 49 of the Civil Code of the Russian Federation). A user assumes certain kinds of restrictions, being guided not only by the express indication of the law, but also based on its own interests. The franchisor provides to the user with the opportunity to use in the process of carrying out entrepreneurial activities a set of created and promoted rights, which have gained recognition and are therefore capable of bringing an economic effect in an amount exceeding the effect of the user's independent actions.
It should also not be forgotten that the user acts voluntarily and freely, limiting itself only for a certain period and preserving the possibility of an earlier exit from the contractual relationship. But these reasons are, in our opinion, of a secondary nature for the user, arising from the legally stipulated admissibility of concluding an agreement with such restrictions.

Therefore, exclusivity in a number of agreements is necessary for their essence, and its absence leads to the actual impossibility of effective execution of such an agreement.

In our opinion, the exclusivity clause should be applied more broadly in any business agreements, but in accordance with their essence.

For example, the norm of para (a), clause 4, article 13 of the Federal Law deted December 28, 2009 No. 381FZ No. "On the Basics of State Regulation of Trade Activities in the Russian Federation" establishes a ban on imposing a condition on a counterparty prohibiting the conclusion of agreements for the supply of food products with other business entities carrying out similar activities (Federal Law dated 28.12.2009 No. 381-FZ No). The imposition of a condition of exclusivity in relation to the supply of goods to retail 
chains allowed Yu.A. Suvorov (2019) to come to the conclusion that "... the conclusion of such agreements in itself between the specified counterparties is not prohibited; only the imposition of such conditions on the other party is prohibited", with which one cannot agree. Here we are talking about the not entirely successful formulation of the aforementioned norm, and not about general permission. With regard to the supply of goods to retail chains, the condition of exclusivity would be beneficial to both parties and there are no significant objections to its application, since the attitude in this case is entrepreneurial and the essence of the relationship justifies such logic.

In contrast to this, the experience of the European Union is interesting, when it takes into account the essence of relations in the absence of a threat of competition. For example, it is expressly permitted to establish an exclusive supply obligation as long as it does not have a significant adverse effect on competition and does not seek to prejudice the rights of the parties to the agreement

(COMMISSION

REGULATION (EC) NO 2790/1999 of 22 December 1999). But as Puya Raad rightly points out (Raad, 2014), this approach is applicable to vertical agreements, most of which are either exempt from antitrust bans or can be otherwise justified for economic and competitive reasons.

The norms of Article 1033 of the Civil Code of the Russian Federation directly provide for the right of the parties to include certain restrictions in the agreement. As rightly indicated in the literature, the conclusion of such an agreement does not automatically mean the application of such restrictions (Sova, 2015). Although such restrictions are considered by us as essential, they cannot be assumed and applied to the relations of the parties in the absence of them in the text of the agreement precisely because of the dispositiveness of paragraph 1, clause 1, Article 1033 of the Civil Code of the Russian Federation.

At the same time, it should be noted that the list of possible restrictions of rights specified in Article 1033 of the Civil Code of the Russian Federation is not exhaustive. Paragraph 1 of clause 1 of this article clearly indicates this: "The agreement of franchising may provide for restrictions on the rights of the parties under this agreement; in particular, they may be provided for..." Therefore, any kind of limitation of rights is not an exception from the general regime of legal capacity of the parties to the 
GÊNERO E

INTERDISCIPLINARIDADE

agreement, but follows from the essence of the agreement, the alleged nature of the user's actions under the guise of the franchisor and the established rules of business. For example, they can not only oblige the user to coordinate with the franchisor the location of commercial premises, their external and internal design, but also determine the design features of the building itself, where the activity is carried out, prohibiting its contact with buildings in which competitors' goods are sold.

The above also does not negate the need for restrictive provisions to comply with the requirements of antimonopoly legislation, taking into account the state of competition in the relevant product market and the economic situation of the parties.

\section{Summary}

A franchise agreement plays a key role in organizing entrepreneurial activity in the form of franchising and is a flexible regulator of these relations. With such a business model, the right to use not only a set of exclusive rights is granted, but also such objects as business reputation or commercial experience, which, in their essence, cannot be the subject of civil transactions. The relationship on their use is regulated only
Vol n 02 | n $^{\circ} 01$ | ISSN: 2675-7451 https://www.periodicojs.com.br/index.php/gei/index

by carefully thought out terms of the franchise agreement in each specific case, taking into account the established practice in the relevant field of business.

\section{CONCLUSION}

The limitation of the rights of the parties under a franchise agreement (exclusivity clause) is permissible, which follows not only from the law, but also from the essence of the agreement. The exclusivity clause should be applied more broadly in any business agreements, but in accordance with their essence.

The list of possible restrictions of rights specified in Article 1033 of the Civil Code of the Russian Federation is not exhaustive and is determined by the essence of the agreement, the intended nature of the user's actions under the guise of the franchisor and the established rules of business turnover.

\section{ACKNOWLEDGEMENTS}

The work is performed according to the Russian Government Program of Competitive Growth of Kazan Federal University.

\section{References}

Baghdasaryan, A.F. Civil law problems of concluding a franchising agreement: 
thesis for the degree of candidate of legal sciences. - Moscow,.- 257 p. (2008).

Dudin, D.I. The counterparty prohibits concluding similar agreements with third parties. When such a prohibition complies with the law. Arbitration practice, 9, P. 57. (2014).

Kulakovsky, V.V. Antimonopoly regulation of a franchise agreement. Property relations in the Russian Federation, 10, 95 - 102(2017).

Raad, P. EFFECTIVENESS OF EU LAW AND POLICY ON VERTICAL RESTRAINTS AT PROTECTING COMPETITION. Wroclaw Review of Law, Administration \& Economics, 3(1), 119-125 [Digital source]. URL: https://cyberleninka.org/article/n/67088 4 (access mode: 06.07.2020). (2014).

Sitdikov, R.B. Legal protection of knowhow in Russia. - M.: Statut,- 144 p. (2017).

Sova, V.V. Agreements on the disposal of the exclusive right to intellectual property: today and tomorrow. Property relations in the Russian Federatio, 12, P.9. (2015).

Suvorov, Yu.A. Agreements on exclusivity" in the light of antimonopoly legislation. Competition law, 1, P.26. (2019).

Yuritsin, A.A. Franchising and franchise agreement: results and prospects of legal regulation: monograph. - M.: Yustitsinform,.- 134 p. (2018).

COMMISSION REGULATION (EC) NO 2790/1999 of 22 December 1999 on the application of Article 81(3) of the Treaty to categories of vertical agreements and concerted practices // Official Journal of the European Communities. 29.12.1999. L 336/2125.EUR-Lex [Digital source]. URL: https://eur-lex.europa.eu/legalcontent/EN/TXT/?uri=CELEX\%3A319 99R2790 (access mode: 06.07.2020). Federal Law dated 28.12.2009 No. 381FZ No. "On the Foundations of State Regulation of Trade Activities in the Russian Federation". Collected Legislation of the Russian Federation. 2010. No. 1. Article 2 